\section{Efficient Water Use in Residential Urban Landscapes}

Rolston St. Hilaire ${ }^{1}$

Plant and Environmental Sciences, New Mexico State University, 352N Skeen Hall, Las Cruces, NM 88003

Michael A. Arnold and Don C. Wilkerson

Horticultural Sciences, Texas A\&M University, College Station, TX 778432133

Dale A. Devitt

Biology, University of Nevada, Las Vegas, NV 89154

Brian H. Hurd

Agricultural Economics and Agricultural Business, New Mexico State University, Las Cruces, NM 88003

Bruce J. Lesikar

Biological and Agricultural Engineering, Texas A\&M University, College Station, TX 77843-2128

Virginia I. Lohr

Horticulture and Landscape Architecture, Washington State University, Pullman, WA 99164

Chris A. Martin

Applied Biological Sciences, Arizona State University, Mesa, AZ 85212

Garry V. McDonald

Horticulture, University of Arkansas, Fayetteville, AR 72701

Robert L. Morris

Cooperative Extension, University of Nevada, Reno, NV 89557

\section{Dennis R. Pittenger}

Cooperative Extension and Department of Botany and Plant Sciences, University of California Riverside, Riverside, CA 92521

David A. Shaw

University of California Cooperative Extension, San Diego County, San Diego, CA 92123-1219

\section{David F. Zoldoske}

Center for Irrigation Technology, California State University, Fresno, CA 93740-0018

Additional index words. conservation, irrigation, landscape preference, ordinance, reuse water, xeriscape

\begin{abstract}
In the United States, urban population growth, improved living standards, limited development of new water supplies, and dwindling current water supplies are causing the demand for treated municipal water to exceed the supply. Although water used to irrigate the residential urban landscape will vary according to factors such as landscape type, management practices, and region, landscape irrigation can vary from $40 \%$ to $70 \%$ of household use of water. So, the efficient use of irrigation water in urban landscapes must be the primary focus of water conservation. In addition, plants in a typical residential landscape often are given more water than is required to maintain ecosystem services such as carbon regulation, climate control, and preservation of aesthetic appearance. This implies that improvements in the efficiency of landscape irrigation will yield significant water savings. Urban areas across the United States face different water supply and demand issues and a range of factors will affect how water is used in the urban landscape. The purpose of this review is to summarize how irrigation and water application technologies; landscape design and management strategies; the relationship among people, plants, and the urban landscape; the reuse of water resources; economic and noneconomic incentives; and policy and ordinances impact the efficient use of water in the urban landscape.
\end{abstract}

Urban areas started as complex social structures $\approx 10,000$ years ago. Many of the earliest urban areas developed in arid climates near reliable fresh river water resources (Redman, 1999). In the modern era, urban and suburban population growth has dramatically changed the balance between consumptive water demand and available supply. This is especially true in portions of the arid and semiarid regions of the western and southern United States where rapid expansion of urban areas has occurred during the last few decades. For example, two decades ago, the entire 7.5 million acre-foot of water of the lower Colorado River basin (Arizona, California, and Nevada) became fully allotted for the first time (Unruh and Liverman, 2008). Additionally, environmental laws crafted to limit ecosystem degradation are constraining the development of new sources of water for the urban environment (Dickinson, 2008). In the future, conservation and rectification programs will become a significant piece of future water management programs for rapidly growing populations (California Department of Water Resources, 2005).

Growing populations in every community in the United States will face different water supply and demand issues. These issues include climate-related differences in water use. In the United States, the yearly average residential water use ranged from a low of $208.4 \mathrm{~L} \cdot \mathrm{d}^{-1}$ per person in the temperate mesic state of Wisconsin to a high of $784.5 \mathrm{~L} \cdot \mathrm{d}^{-1}$ in the arid state of Nevada (Emrath, 2000). This indicates that climate-related differences in outdoor water use contribute significantly to the high water use in arid western states (Emrath, 2000). Landscape irrigation contributes to most of southern Nevada's consumptive water use (Sovocool et al., 2006). With reports that landscape water use averages $40 \%$ to $70 \%$ of residential water use in the United States (Ferguson, 1987) and increasing frequency of summer droughts in parts of the United States (such as the northeast) that are unaccustomed to droughts (Wolfe et al., 2008), it is clear that efficient water use in the outdoor environment will become part of long-term public strategies for conserving natural resources.

Received for publication 22 May 2008. Accepted for publication 21 Aug. 2008.

Contribution of the NM Agr. Expt. Sta., NM State Univ. and CSREES-USDA under Agreement Nos. 2005-34461-15661 and 2005-45049 entitled Efficient Irrigation for Water Conservation in the Rio Grande Basin. We acknowledge the contributions of Clare Bowen-O'Connor, Jeannie Castillo, Victoria Frietze, Genhua Niu, Cheri Vogel, Phillip King, Raul Cabrera, John Longworth, and Ursula Schuch who were participants of the First Symposium on Efficient Water Use in the Urban Landscape held at NM State Univ. We thank Craig Runyan and Leeann DeMouche for technical support. Scholarly contributions to this symposium formed the basis of this paper. All authors contributed equally to this review.

${ }^{1}$ To whom reprint requests should be addressed; e-mail rsthilai@nmsu.edu 
Improvements in efficiency of landscape irrigation delivery systems could potentially yield significant water savings because watering residential landscapes is the greatest household use of water. Water-efficient landscapes have been promoted for decades (Denver Water Department, 1982; Lohr, 1991; Rooke, 1974), but in some communities, only drastic measures or catastrophic events have caused water-efficient landscapes to be implemented. For example, in 1981, a court ordered the Denver Water Department to promote water conservation in outdoor landscapes (Hagan, 1988). Faced with dwindling water supplies, in 2002, the city of El Paso, TX, amended its municipal code (Section 15.13.130) to restrict turf areas to $50 \%$ or less of the total outdoor landscaped area (City of El Paso, 1991). On 17 Sept. 2007, the state of Georgia simply banned outdoor watering because of a severe drought (Brown and Pharr, 2007). The estimated impact of the drought on Georgia's urban agriculture sector is $\$ 3.5$ billion. Thus, improvement in urban water conservation is applicable not only to western states, but is also relevant to other areas within the United States. Furthermore, expected increases in the earth's average temperature will increase evapotranspiration, which could exacerbate drought conditions (Natural Defense Resource Council, 2008). Higher temperatures will increase evaporation from outdoor water features and elevate evapotranspiration from plants. Both of those occurrences will augment the demand for water in the outdoor environment.

Consumers do not always envision waterefficient landscapes to be attractive and aesthetically pleasing (Lohr and Bummer, 1992). So, many municipalities are mandating the use of water-efficient landscapes as part of their water conservation programs (Smith and St. Hilaire, 1999) and public relations campaigns. Thus, consumers will have to install water-efficient landscapes and may need information on the potential benefits of those landscapes. Furthermore, the urban landscape is the first area that water districts and government agencies regulate for water use because of its high public visibility (Devitt et al., 1995).

Urban landscapes contribute as much as $20 \%$ of the fair market value of a residential property (Council of Tree and Landscape Appraisers, 2003). So, the loss of some landscape elements such as trees and shrubs because of ill-conceived water restrictions or unmitigated drought could severely depress property values. Estimating the impact of drought on urban landscape elements such as trees is difficult (Graves, 1996). A case study revealed that the drought of 1990 caused countywide losses of \$234 million for shrubs, lawns, and groundcovers and $\$ 192$ million for trees in Santa Barbara, CA (Moore et al., 1993).

Improving efficiency of water use in the urban landscape is impacted by landscape irrigation and water application technologies (California Office of Water Use Efficiency,
2006), the relationship among people, plants, and water-efficient landscapes (Balok and St. Hilaire, 2002; Lohr, 1991; Martin and Stabler, 2004), reuse of water resources (Arnold et al., 2003; Devitt et al., 2003), economic and noneconomic incentives (Hurd et al., 2006), and policy and ordinances. The objective of this article is to review how those factors contribute to efficient water use in the urban landscape.

\section{Landscape Irrigation and Water Application Technologies}

Landscape irrigation. Landscape irrigation is the systematic application of water to land areas that supply the water needs of ornamental and landscape plants. Landscape irrigation involves several methods such as low-volume application, flood, and sprinkler systems. In this review, we focus on sprinkler irrigation, which is a network of pipes that discharge water through nozzles to the landscape. Landscape irrigation includes the design (engineering), water management (when and how much water to apply), equipment (pipes, valves, emission devices, controllers, and so on), installation, and maintenance. Components or activities associated with the irrigation system must work cohesively because a fault in any one of these items or activities negatively impacts water use efficiency. From an irrigation standpoint, water use efficiency is a product of the application uniformity and how well water is managed to meet plant water demands. So, to guarantee the most efficient use of water in the urban landscape, the consumer must seek the highest possible level of uniformity and management.

Landscape irrigation uniformity. The goal of landscape irrigation uniformity is to apply water to the landscape as evenly as possible. Most irrigation scheduling is driven by the areas that receive the least amount of water. These areas are commonly referred to as dry spots. However, applying more water to the dry spots overirrigates the rest of the landscape. Therefore, the aim of highly uniform water application is to reduce the difference between the minimum and maximum wetted areas (Zoldoske et al., 1994).

Given site and design parameters, the expected uniformity of an irrigation system can be modeled before it is installed (Oliphant, 1989). To better irrigate the landscape, it is recommended that irrigators specify irrigation application uniformity in a contract before purchasing an irrigation system. After installation, the system can be audited to verify the system performance.

The basis for calculating irrigation uniformity of an overhead irrigation system can be easily derived from a single-leg sprinkler profile test. For a single-leg sprinkler profile test, catch cans are spaced equally starting from the sprinkler head and extending beyond the wetted radius of throw of the sprinkler. A catch can is an open container placed in the radius of throw of the sprinkler to catch water from the sprinkler. Only one sprinkler is operated during the test period and the water application rate of the sprinkler determines the test duration. A minimum catch-can reading of $3 \mathrm{~mm}$ in the driest catch can is suggested (ASAE S398.1; American Society of Agricultural and Biological Engineers, 1985). These tests can be performed either in an indoor laboratory or outside in the field (Fig. 1). Also, various combinations of sprinkler model, nozzle size, and operating pressure can be tested.

Once the profile test is completed, water application uniformity, as measured in the overlap area, can be calculated statistically by using computer programs such as SPACE Pro (Oliphant, 1989). Three common ways of calculating water application uniformity for landscape irrigation include: coefficient of uniformity (CU), distribution uniformity (DU), and scheduling coefficient (SC) (Burt et al., 1997). Historically, CU has been one of the most referenced measures of uniformity in agricultural irrigation (Zoldoske et al., 1994). Because CU fails to distinguish between over- and underirrigated areas, its application to turf irrigation is limited. Thus, DU and SC are the more widely used measures of landscape irrigation uniformity.
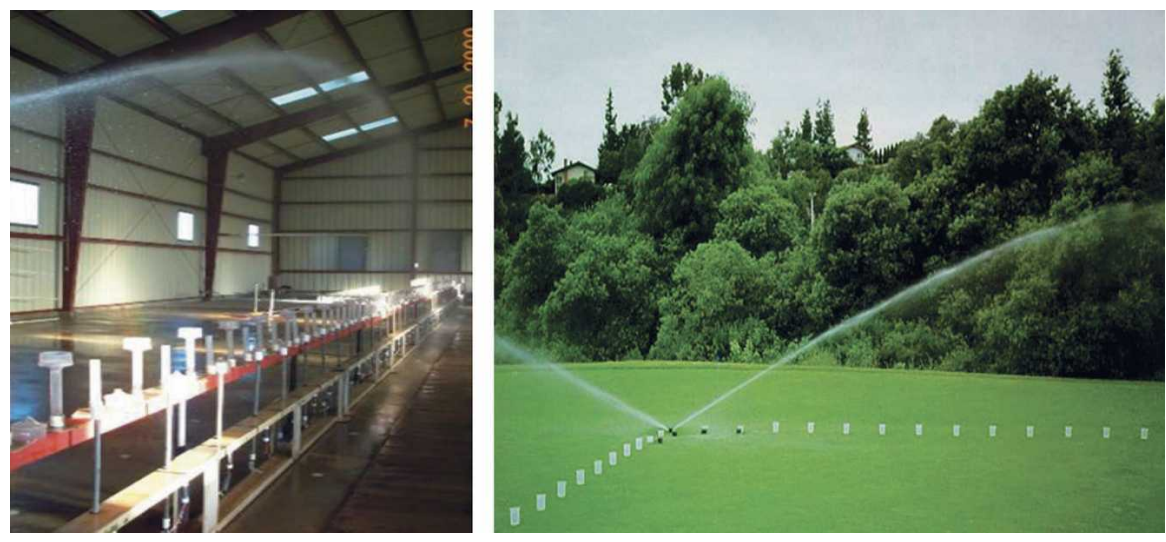

Fig. 1. Indoor (left panel) and outdoor (right panel) single leg sprinkler profile testing of sprinkler uniformity. Catch-cans are spaced equally along a straight line that starts from the sprinkler head and extends beyond the wetted radius of throw of the sprinkler. 
Distribution uniformity is a measure of the low quarter or driest $25 \%$ of the coverage area compared as a ratio with the average uniformity. The DU is commonly used in landscape irrigation field audits. However, DU provides the average precipitation to the underirrigated area and does not show the size or shape of the dry area(s). A densogram (Fig. 2) shows graphically the wetter areas (higher precipitation) and drier areas (lower precipitation) within the sprinkler coverage area (Oliphant, 1989). The densogram provides the landscape irrigator with an overview of the water distribution patterns within the sprinkler coverage area (Solomon, 1989). Spatial patterns should be carefully examined because abnormal spatial patterns can exist at CU/DUs that appear to be acceptable. Abnormalities in spatial patterns are a revealing sign that sprinkler adjustments may be needed immediately or at some future time. Sprinkler spatial patterns will change as system parts deteriorate or as sprinkler heads are knocked off alignment by carts or mowers. Irrigation systems that deliver reuse water should be evaluated more often than irrigation systems that use potable water.

Scheduling coefficient is another way to determine sprinkler irrigation uniformity. The SC uses a ratio of average application rate compared with the average found in the driest continuous application area (usually specified as $1 \%, 5 \%$, or $10 \%$ of the pattern area). This ratio, which must be one or greater, is used to estimate how long the irrigation system must run to apply the minimum needed water to the driest area. The larger the SC number, the longer the system must operate to wet the dry spots. For example, an irrigation system with an SC of 1.5 would have to run $50 \%$ longer than a perfectly uniform system with an SC of 1.0 to apply equal amounts of water to the driest part of the coverage area. The SC is operationally the converse of the DU because DU defines the mean of $25 \%$ of lowest volume in catch cups for DU, whereas SC identifies the amount of water needed for the driest spot.

Landscape irrigators must recognize that irrigation uniformity depends on the sprinkler profile and sprinkler field spacing. Efficient irrigation in the urban landscape requires an understanding of how sprinkler profiles and spacing can impact uniformity distributions. A sprinkler on an 18.3-m $\times$ 15.9-m triangular spacing has a CU of $93 \%$, a DU of $88 \%$, and a SC of 1.4 . If that same sprinkler is then spaced at a $21.3-\mathrm{m} \times 18.6-\mathrm{m}$ triangular spacing, the uniformity is reduced to $79 \% \mathrm{CU}, 64 \% \mathrm{DU}$, and $2.2 \mathrm{SC}$ (Fig. 3). The increased distance between the sprinkler heads represents a $24 \%$ reduction in DU. The DU decreases because the spacing is greater than the recommended spacing for this sprinkler model. Both CU and SC also decrease.

Water budgets and irrigation scheduling. In addition to specifying the uniformity of water application, landscape irrigators must accurately determine water budgets and irrigation schedules. As a way to reduce water applied to urban landscapes, water purveyors,



Fig. 2. A densogram that shows three sprinkler heads (green circles) contributing to the repeating coverage area. The area outlined in the top left of the densogram indicates the wettest, continuous $5 \%$ of the coverage area. Conversely, the area shown enclosed by box located near the center shows the driest continuous $5 \%$ area.

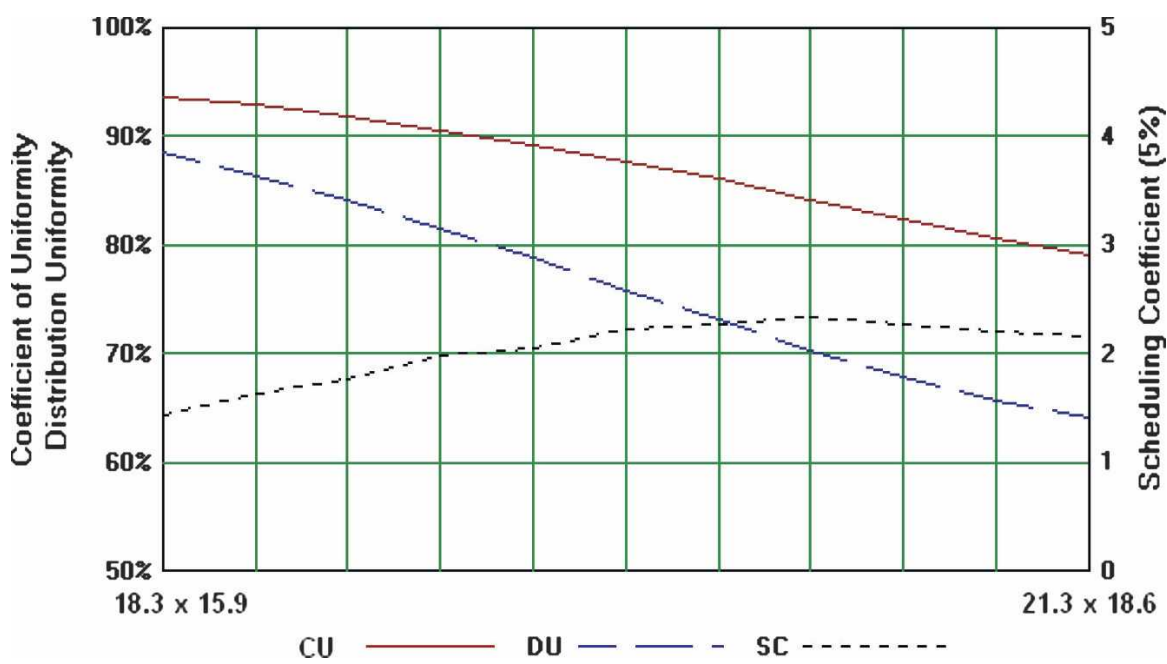

Fig. 3. Changes in coefficient of uniformity (CU), distribution uniformity (DU), and scheduling coefficient (SC) as the triangular sprinkler spacing is increased from $18.3 \mathrm{~m} \times 15.9 \mathrm{~m}$ to $21.3 \mathrm{~m} \times 18.6$ $\mathrm{m}$. Other data points and spacings are represented in the graph between these two extremes.

local governments, and landscape management professionals are using reference evapotranspiration $\left(\mathrm{ET}_{\mathrm{o}}\right)$ to determine climatebased water budgets and irrigation schedules for landscape sites (California Office of Water Use Efficiency, 2006; California Urban Water Conservation Council, 1991; Colorado Department of Local Affairs, 2004; King County Department of Development and Environmental Services, 2003). Reference crop $\mathrm{ET}_{\mathrm{o}}$ is evaporatranspiration (ET) from a reference surface that is well-watered. The reference surface approximates a $12-\mathrm{cm}$ tall reference crop with a fixed surface resistance of $70 \mathrm{~s} \cdot \mathrm{m}^{-1}$ and an albedo (reflectance) of 0.23 (Allen et al., 1998). Calculating accurate and effective $\mathrm{ET}_{\mathrm{o}}$-based water budgets and irrigation schedules requires multiplying $\mathrm{ET}_{\mathrm{o}}$ by a reliable adjustment factor (AF) (King County Department of Development and Environmental Services, 2003; State of California, 1993). An urban 
landscape's water budget, also known as its maximum applied water allowance (MAWA), is calculated by:

Water budget or MAWA (in gallons) =

$\mathrm{ET}_{\circ}$ (inches) $\times \mathrm{AF} \times$ landscape $\operatorname{area}\left(\mathrm{ft}^{2}\right)$.

The AF is effectively, although not technically, a crop coefficient $\left(\mathrm{K}_{\mathrm{c}}\right)$ that corrects the $\mathrm{ET}_{\mathrm{o}}$ value to account for the water needs of the plants (Allen et al., 1998). However, the typical urban landscape does not conform to the standard conditions under which $\mathrm{ET}_{\mathrm{o}}$ and $\mathrm{K}_{\mathrm{c}} \mathrm{S}$ are defined and estimated. Ornamental crop coefficients often are given for an agricultural-type crop that achieves full yield while growing in large fields under excellent agronomic and soil water conditions (Allen et al., 1998). Conversely, urban landscapes are diverse mixes of turfgrass, woody, and herbaceous plant species that are valued for their appearance, not their yield. So, the concept of optimum growth and yield is not relevant to the urban landscape (Shaw and Pittenger, 2004). Additionally, woody ornamental plants and shrubs in an urban landscape do not form the uniform surface defined in the $\mathrm{ET}_{\mathrm{o}}$. From an urban landscape perspective, standard $\mathrm{ET}_{\mathrm{o}}$ definitions are relevant to turf but not to trees and shrubs.

Water needs of nonturf landscape plants are more appropriately defined as the percentage of $\mathrm{ET}_{\mathrm{o}}$ required to maintain their appearance and intended function (Pittenger et al., 2001; Shaw and Pittenger, 2004). In addition, the water use rates of many woody species are not a direct linear function of $\mathrm{ET}_{\mathrm{o}}$, and many nonturf landscape plants can maintain acceptable aesthetic appearance at some level of moisture deficit (Kjelgren et al., 2000). Therefore, to optimize the efficiency of water use in the urban landscape, $\mathrm{ET}_{\mathrm{o}}$ adjustment factors for landscape plants should define the minimum irrigation a plant needs to maintain acceptable aesthetics and defined landscape function (e.g., green foliage, screening element). This adjustment factor is properly termed a plant factor (PF) rather than a $\mathrm{K}_{\mathrm{c}}$ because of the emphasis on plant appearance rather than optimum growth and yield.

The application of multiplying $\mathrm{ET}_{\mathrm{o}}$ by some form of AF value to estimate landscape plants' water needs is a rational, weatherbased approach for managing and conserving water applied to landscapes (Kjelgren et al., 2000; Snyder and Eching, 2006). Using $\mathrm{ET}_{\mathrm{o}} \times$ $\mathrm{K}_{\mathrm{c}}$ has been an effective tool for scheduling irrigation in turfgrass because turfgrass swards closely mimic the standard conditions of $\mathrm{ET}_{\mathrm{o}}$ estimation (Devitt et al., 1992; Gibeault et al., 1990). Crop coefficients have been developed for minimum and optimum performance of cool-season grasses (64\% and $80 \%$ of $\mathrm{ET}_{\mathrm{o}}$, respectively) and warmseason grasses $\left(36 \%\right.$ and $60 \%$ of $\mathrm{ET}_{\mathrm{o}}$, respectively) (Meyer et al., 1985).

Using the $\mathrm{ET}_{\mathrm{o}} \times \mathrm{PF}$ formula effectively estimated the water needs and irrigation schedules for landscape groundcovers and shrubs (Pittenger et al., 2001; Shaw and
Pittenger, 2004; Staats and Klett, 1995). However, this formula was less suitable in estimating water needs of isolated landscape trees (Devitt et al., 1994; Montague et al., 2004).

Most field studies on determining PFs of landscape plants have been conducted in the western United States where landscapes routinely are irrigated. Studies on irrigation of landscape groundcovers in southern California and Colorado demonstrate several species perform acceptably when applied water is $20 \%$ or $50 \%$ of $\mathrm{ET}_{\mathrm{o}}$, making them suitable species for water-conserving landscapes (Pittenger et al., 2001; Staats and Klett, 1995) (Table 1). A similar 3-year investigation was conducted with 30 shrub species receiving irrigation amounts of $0 \%, 18 \%$, and $36 \%$ of $\mathrm{ET}_{\mathrm{o}}$ at the immediate coast of southern California (Shaw and Pittenger, 2004) (Table 1). Although the aesthetic appearance of most species was reduced with less water, 11 species maintained acceptable appearance with no irrigation and another 14 species did so at $18 \%$ of $\mathrm{ET}_{\mathrm{o}}$. Many species exhibited reduced growth rates with less water applied. The study location, however, is characterized by relatively low $\mathrm{ET}_{\mathrm{o}}$ rates (Allen et al.,

1998) and there are fog contributions to plant water needs. Species performing acceptably with no irrigation would likely need some applied water when grown away from the coast where $\mathrm{ET}_{\mathrm{o}}$ rates are higher and there are no fog contributions to plantings.

Although using the $\mathrm{ET}_{\mathrm{o}} \times \mathrm{PF}$ formula is a powerful way to optimize urban landscape irrigation, there is a lack of research-based PFs for landscape plants. A widely referenced publication containing an extensive listing of $\mathrm{PF}$ ranges for landscape plant species (Costello and Jones, 2000) is non research-based. Models have been derived for woody ornamentals' water use in a container production system (Beeson, 2005), but Schuch and Burger (1997) showed that $\mathrm{K}_{\mathrm{c}} \mathrm{s}$ from containerized plants are of limited value. Furthermore, Vrecenak and Herrington (1984) cautioned that water use of some tree species can be modeled only if they are kept well-watered. Lysimeter-based studies conducted with landscape trees illustrate that water use of some species increases with increased soil moisture content and/or plant size, but results vary by species (Devitt et al., 1994, 1995; Vrecenak and Herrington, 1984). None of the previously mentioned

Table 1. Water needs as a percentage of reference evapotranspiration for selected landscape groundcovers and shrubs to provide acceptable landscape performance after establishment. ${ }^{z}$

\begin{tabular}{|c|c|c|}
\hline Scientific name & Common name & $\begin{array}{c}\text { Percent } \\
\text { evapotranspiration }\end{array}$ \\
\hline Arbutus unedo L. 'Compacta' & Compact strawberry tree & $18-36$ \\
\hline Arctostaphylos uva-ursi (L.) Spreng. 'Pacific Mist' & Bearberry & $18-36$ \\
\hline Artemisia $\times$ 'Powis Castle', L. & Workwood & $0-36^{\mathrm{y}, \mathrm{w}}$ \\
\hline Baccharis pilularis (L.) DC. 'Twin peaks' & 'Twin Peaks' coyote bush & 20 \\
\hline Calliandra haematocephala Hassk. & Pink powder puff & $18-36$ \\
\hline Cassia artemisioides Gaud. & Feathery cassia & $0-36^{\mathrm{y}, \mathrm{x}}$ \\
\hline Cerastium tomentosum, L. & Snow-in-summer & 25 \\
\hline Cistus $\times$ purpureus Lam. & Orchid spot rock rose & $0-36^{y}$ \\
\hline Correa alba Andr. 'Ivory Bells' & White australian correa & $18-36$ \\
\hline Drosanthemum hispidum (L.) Schwant. & Pink iceplant & 20 \\
\hline Echium fastuosum Jacq. & Pride of madeira & $0-36^{\mathrm{y}}$ \\
\hline Escallonia $\times$ exoniensis Veitch. 'Fradessii' & Frades escallonia & $18-36$ \\
\hline Galvezia speciosa Gray. & Bush snapdragon & $0-36^{\mathrm{y}, \mathrm{x}}$ \\
\hline Gazania rigens var. leucolaena (DC.) Roessler. & Yellow trailing gazania & $50-80$ \\
\hline Grevillea $\times$ 'Noel' Knight. & Noell grevillea & $0-36^{\mathrm{y}}$ \\
\hline Hedera helix L. 'Needlepoint' & 'Needlepoint' english ivy & $20-30$ \\
\hline Heteromeles arbutifolia, M. J. Roemer. & Toyon & $0-36^{y}$ \\
\hline Hibiscus rosa-sinensis L. & Rose of china & $40-60$ \\
\hline Lantana montevidensis Briq. & Trailing lantana & $18-36$ \\
\hline Leptospermum scoparium J. R. Forst \& G. Forst & New zealand tea tree & $18-36$ \\
\hline Leucophyllum frutescens I. M. Johnst. 'Green Cloud' & 'Green Cloud' texas ranger & $0-36^{\mathrm{y}, \mathrm{x}}$ \\
\hline Ligustrum japonicum Thunb. 'Texanum' & Texas privet & $40-60$ \\
\hline Myoporum $\times$ 'Pacificum' Banks \& Sol. ex Forst. F. & Prostrate myoporum & $0-36^{\mathrm{y}}$ \\
\hline Otatea acuminate (Munro) C.E. Calderon \& Soderstr. & Mexican bamboo & $18-36$ \\
\hline Phormium tenax J. R. Forst \& G. Forst. & New zealand flax & $18-36$ \\
\hline Pittosporum tobira Ait. & Mock orange & $18-36$ \\
\hline Potentilla tabernaemontanii, Asch. & Spring cinquefoil & $70-80$ \\
\hline Prunus caroliniana Ait. & Carolina laurel cherry & $0-36^{\mathrm{y}}$ \\
\hline Pyracantha koidzumii Rehd. 'Santa Cruz' & 'Santa Cruz' firethorn & $0-36^{\mathrm{y}}$ \\
\hline Rhaphiolepis indica Lindl. & Indian hawthorne & $18-36$ \\
\hline Sedum acre L. & Goldmoss & $0-25$ \\
\hline Teucrium chamaedrys L. & Germander & $18-36$ \\
\hline Vinca major L. & Periwinkle; myrtle & $30-40$ \\
\hline Westringia rosamarinaformis $\mathrm{L}$. & Rosemary bush & $18-36$ \\
\hline Xylosma congestum Merrill. & Shiny xylosma & $18-36$ \\
\hline
\end{tabular}

zPittenger et al. (2001), Shaw and Pittenger (2004), Staats and Klett (1995).

${ }^{y}$ Acceptable landscape performance with no summer irrigation shown only at the immediate coast. Inland plantings may require summer irrigation up to the maximum amount listed.

${ }^{x}$ Species typically provides unacceptable landscape performance in summer and fall month irrespective of irrigation amount.

${ }^{\text {w}}$ Requires renovation every 3 years to maintain acceptable performance. 
studies quantified tree water use as a percentage of $\mathrm{ET}_{\mathrm{o}}$ or evaluated plant aesthetic responses. Also, these approaches have not produced widely applicable information for estimating reliable PFs of landscape plants in terms of the amount of water needed for them to simply maintain acceptable appearance and landscape function. Clearly, there is a need for research that generates PFs for multiple species.

Where research-based studies that determine PFs for landscape trees have been reported, they show amazing possibilities for water conservation. For example, a 4-year study of young oaks transplanted in an urban landscape setting in the San Francisco Bay area showed that irrigation at $0 \%, 25 \%$, or $50 \%$ of $\mathrm{ET}_{\mathrm{o}}$ had no effect on their growth after they were provided a well-watered 1-year establishment period (Costello et al., 2005). Although these oaks grew naturally in the San Francisco Bay area and we expect less growth with less water, many commonly grown landscape plants are capable of maintaining aesthetic and functional value when irrigated at substantially less than $100 \%$ of $\mathrm{ET}_{\mathrm{o}}$.

Smart water application technologies. One way to schedule irrigation that is based on $\mathrm{ET}_{\mathrm{o}}$ is to use Smart Water Application Technologies (SWAT ${ }^{\mathrm{TM}}$ ). SWAT ${ }^{\mathrm{TM}}$ is a national initiative designed to achieve exceptional landscape water use efficiency through the use of irrigation technology. SWATTM identifies, researches, and promotes technological innovations and related management practices that advance the principles of efficient water use. An integral part of SWAT ${ }^{\text {TM }}$ is the use of smart controllers. Different products on the market use a wide array of technologies and proprietary algorithms. The technologies and user interfaces vary in complexity from traditional controller features and layouts to Internet-based management and interface (U.S. Bureau of Reclamation, 2007). Some smart controllers can continually monitor changing weather or soil conditions (through soil moisture sensors) and use the data to schedule irrigations intended to meet the plant's water demand. Others use historical ET data.

Smart controllers also must account for precipitation in the irrigation schedule. Most in-ground irrigation systems are operated by a controller that requires frequent input from the operator (homeowner) to adjust the daily or seasonal irrigation run times. Most homeowners set the irrigation schedule to meet peak irrigation demand and do not seasonally adjust their irrigation schedules. Frequently, overirrigation occurs during periods of reduced plant water demand such as the fall to winter period (Davis et al., 2007). During those periods, water demand is decreasing and the corresponding irrigation run times are not adjusted accordingly. In theory, with smart controllers, the decision to irrigate is removed from the hands of the operator. However, research indicates that their use does not eliminate human interaction with the controller, and they require someone with technical knowledge in horticulture and landscape irrigation management to setup (Pittenger et al., 2004; Shedd et al., 2007). Some smart controllers require users to calculate an accurate base irrigation schedule in the setup process, whereas others need technical, site-specific data and horticultural parameters to set up. All smart controllers require follow-up auditing by the installer or user to determine whether the derived irrigation schedules are appropriate and that plants are adequately but not overwatered. Manual adjustments to the controller's program often are necessary for the device's irrigation schedule to meet accurately the water needs of a landscape. Although very few controlled studies have evaluated the water-conserving performance of smart controllers, it has been estimated that certain smart controllers could reduce summertime-applied water by up to 42 gallons per day for residential landscapes and up to 545 gallons per day for commercial landscapes plus reduce runoff by $64 \%$ to $71 \%$ (Irvine Ranch Water District, 2008a). Most of the studies on the reliability and waterconserving capabilities of these controllers have been observational. Few used a sound experimental control or referenced applied water to real-time $\mathrm{ET}_{\mathrm{o}}$ and scientific evaluations of plant performance.

Because smart controllers offer the potential to realize significant water savings, several municipalities are either offering rebates for their use (San Diego County Water Authority, 2008; Southern Nevada Water Authority, 2008) or are mandating their installation (Conservation Current, 2008). However, to be effective, smart controllers must meet basic performance standards. The Irrigation Association has established a laboratory testing protocol to characterize the efficacy of smart irrigation system controllers that use climate, soil, or plant data as a basis for scheduling irrigation events (Irrigation Association, 2008).

Soil moisture sensors are another promising technology that can improve irrigation efficiency in the urban landscape. Soil moisture sensors can provide closed-loop feedback to time-based system controllers. This allows controllers to recognize soil moisture levels and end irrigation events when soil moisture reaches set levels. More sophisticated controllers can use soil moisture readings to determine frequency and duration of irrigation events. Because moisture levels, soil type, and salinity might impact their sensitivity, soil moisture sensors must be evaluated under a wide range of field conditions to gauge their effectiveness. Also, the operating principles of soil moisture sensors can range from electrical conductivity (EC) and time domain reflectometry (TDR) to soilmoisture tension and heat dissipation. Each of these principles has inherent strengths and limitations. For example, soil salinity levels above $6 \mathrm{dS} \cdot \mathrm{m}^{-1}$ will impact TDR-based sensors less than EC-based sensors such as gypsum blocks (Muñoz-Carpena, 2004). So, the landscape irrigator might have to balance sensor calibration requirements, precision, and accuracy with cost.

\section{People, Plants, and Water-efficient Landscapes}

Attitudes to water-efficient landscapes. When people think of water-efficient landscapes, they should envision attractive, inviting landscapes. If large expanses of gravel interspersed with a few drought-tolerant plants are what come to mind, then people will not be eager or willing to install waterefficient landscapes. One of the highest rated barriers to installing a water-efficient landscape is "aesthetic concerns" (Hurd et al., 2006). However, with the perception that traditional landscape functions can be preserved while using water-efficient landscapes, consumers may select those landscapes as a way to conserve water (Spinti et al., 2004).

Attitudes toward water-efficient landscapes have been examined for decades (Cotter and Croft, 1974; Lohr and Bummer, 1992; Thayer, 1982). This attention has apparently not led to a public appreciation for these landscapes and their potential impact on water conservation. Residents in Lubbock, TX, were asked about the following statement: "Water-conserving landscapes are aesthetically pleasing"; only $9 \%$ agreed or strongly agreed with the statement, whereas $61 \%$ disagreed or strongly disagreed (Lockett et al., 2002). In New Mexico, urban homeowners are aware of local water issues; $72 \%$ reported that water issues were among the most important in their community, and $84 \%$ felt that homeowners were very responsible or fairly responsible for water conservation (Hurd et al., 2006). Yet, when categorizing their own landscapes, 34\% selected "rocks, gravel, and bare soil"; this description is often associated with barren urban landscapes that are erroneously classified as water-conserving.

Traits associated with inviting and desirable water-consumptive landscapes can be readily incorporated into water-efficient landscapes. Many books and articles summarizing the research on people's landscape preferences and responses to plants are available (Kaplan and Kaplan, 1989; Lewis, 1996; Relf and Lohr, 2003; Smardon, 1987; Zube et al., 1982). Incorporating principles learned from this can ensure that water-efficient landscapes are appealing.

Urban landscape preferences. People prefer landscapes with trees, especially large trees, to those without them (Dwyer et al., 1991; Kaplan, 1985; Schroeder and Cannon, 1987; Spinti et al., 2004). Trees elicit strong feelings in people and provide shade, cooling, and protection. Trees are valued more for their function in the landscape than for their perceived impact on property values (Spinti et al., 2004). For water-efficient landscapes to be desirable, trees must be used in the landscape design.

People respond positively to trees of any shape, but we respond slightly more positively to trees with a spreading shape than to trees of round or columnar shapes (Lohr et al., 2004; Sommer, 1997; Summit and Sommer, 1999). The color of plants also 
affects people's responses. Physiological measures showed that people respond positively to trees of any color, even unusual colors (Kaufman and Lohr, in press). People responded most positively to trees with a green canopy that resembles the green of a young, vigorous tree. They were more relaxed when looking at tree canopies that were deep green than when looking at canopies in other colors such as yellow-green, red, or blue. Many water-conserving plants are grayish green, a color that reflects more heat than deeper green (Richards et al., 1986). Some deep and bright green plants are also water-conserving. Some may, for example, have vertically oriented leaves, thick cuticles, or dense hairs that help conserve water (Chaves et al., 2003; Kirsch et al., 1997). By using some plants that are bright green, along with grayish green or bluish green plants, the appeal of the landscape might be increased.

People prefer coherent (orderly) landscapes (Herzog and Leverich, 2003; Kaplan et al., 1998). Defined areas such as planting beds contribute to an orderly understanding of a landscape and thus to its coherency. Clutter such as the random scattering of plants across a landscape distracts from coherency. Harmony with elements and discernible patterns also contribute to coherency and thus to preferred landscapes whether they are traditional or water-efficient (Cotter and Croft, 1974).

People prefer landscapes with some mystery or indication that there is more to explore within the landscape (Kaplan and Kaplan, 1989). Expanses of gravel with a few scattered plants contain no mystery and leave nothing of interest for us to contemplate and little to interest us in entering and exploring the landscape. A sense of mystery within a landscape can come from partially obscured views or paths that curve out of sight, making us wonder about what lies beyond our view (Gimblett et al., 1985; Herzog, 1987; Kaplan and Kaplan, 1989). The appeal of a landscape will be increased if these elements are incorporated.

Although mystery is a valuable element in the urban landscape, in arid climate regions of the United States such as the Sonoran Desert, there might be a paradigm shift in how the overall landscape is valued. The urban landscape function as a measure of the value of outdoor living space appears to be superseded by a landscape form driven by public interest in flora and water conservation. Thus, the new role of the urban landscape in arid regions may be to visually enhance the indoor human living experience while reflecting an attempt to conserve natural resources and offer city dwellers an opportunity to comfortably experience nature.

However, a distinct incongruence may exist between the prevalence of waterconserving landscape designs of publicly controlled spaces and the landscape preferences of homeowners (Martin et al., 2003). Homeowners most often preferred an oasis land- scape design with a mixture of desert-adapted plants, mesic plant species, and turfgrass lawns (Martin et al., 2003). That homeowners report a greater preference for waterconserving landscapes in their front yard than their backyard (Spinti et al., 2004) further supports this incongruence. The prevalence of water-conserving landscapes, especially in the arid southwestern United States, reflects the increased influence of those landscape designs as a contemporary landscape style. However, traditional landscapes are still fixtures in the urban residential landscape. This suggests that the emergent popularity of water-conserving landscapes might be a predominantly a top-down social phenomenon directed by public and private interest groups for residential homeowner use.

Regardless of the type, landscapes must be managed appropriately to maximize plant water use efficiency. For example, frequent irrigation of desert landscape vegetation stimulates plant growth and increases plant pruning to control plant size. In a managed urban landscape in Phoenix, AZ, the generation of landscape shrub green waste as a percentage of total annual productivity varied with pruning method and frequency (Stabler and Martin, 2004). Landscape shrub waste ranged from $8 \%$ for unpruned shrubs to $38 \%$ or $41 \%$ for those shrubs pruned every 6 weeks or 6 months, respectively. These findings underscore the importance of optimizing irrigation and pruning practices to improve landscape plant water use efficiency.

Xeriscaping. Many municipalities in arid and semiarid regions of the United States are advocating landscape water conservation through the use of xeriscapes (Smith and St. Hilaire, 1999). A xeriscape ${ }^{T M}$ is a landscape designed explicitly to conserve water. Xeriscaping is based on seven basic principles; start with a good plan and design for the urban landscape, use an efficient irrigation system, select appropriate turf areas, choose appropriate plant material, improve the soil, use mulches, and use good maintenance techniques.

Starting with a good plan and design for an urban landscape is an important step in xeriscaping because water efficiency can be incorporated into the landscape design at the onset. Landscape areas can be grouped according to water use. Irrigation efficiency improves when plants with comparable irrigation needs are grouped into areas that reflect their water demands (Schuch and Burger, 1997).

Xeriscaping advocates the use of turf species that are regionally appropriate. Because turf areas might require more frequent maintenance and water than other areas of the landscape, xeriscaping requires that the turf area should be sized just to meet the needs of the end user (Smith and St. Hilaire, 1999). Equally important as choosing appropriate turf areas is selection of other groundcovers, trees, and shrubs that will thrive in a xeriscape $^{\mathrm{TM}}$. Horticulturists must select judiciously taxa that are destined for xeriscapes. Several xeric plants have adapted to surviv- ing drought but not to use water efficiently (Tipton, 1994). Furthermore, some plants recommended for xeriscapes can become weedy or escape cultivation and become invasive if overwatered (Smith and St. Hilaire, 1999). For example, canary island broom (Genista canariensis L.), scotch broom [Cytisus scoparius (L.) Link], and spanish broom (Spartium junceum L.) have good ornamental traits and thrive in xeriscapes. However, these plants have escaped from managed landscapes and are invasive species in California and the northwest.

Urban landscapes often are established on subsoils or soils that are compacted from construction activity. Simple soils tests can be used to guide soil improvements. For example, information on soil nutrient status could be used to determine the type and amounts of amendments to incorporate into the soil. Once the soil is prepared, mulches can be placed over the soil to assist in moisture retention by moderating soil temperature and preventing soil desiccation (Smith and St. Hilaire, 1999).

Thus, a properly implemented xeriscape ${ }^{\mathrm{TM}}$ has the potential to reduce water consumption without compromising functionality and beauty of the urban landscape. A 5-year study has shown that xeriscapes in Las Vegas, NV, single-family homes use $76 \%$ less water than turfgrass landscapes (Sovocool et al., 2006). To fully realize the water savings of xersicapes, emphasis must be placed on the irrigation system. In water conservation programs in which participants converted from turf to xeriscapes, $66 \%$ of the water savings was attributed to the improved efficiency of the irrigation system that the programs mandated.

\section{Using Reuse Water in Urban Landscapes}

Water quality and health risks. Using reuse water to irrigate urban landscapes is one way a community can extend the usefulness of its existing water resources and improve irrigation efficiency. For the state of California, Dickinson (2008) cautioned that conservation efforts will not meet the state's water requirements and that water reuse programs will be needed to satisfy the water shortfall. This is also true for several other states. However, reuse water must be safe, a distribution system will be needed to move the reuse water throughout the community, and it must be economical to use. The public's negative perceptions and attitudes toward reuse water might have to be addressed before reuse water gains widespread acceptance. Communities more favorably view reuse water as a valuable resource if they understand their water situation and know the available alternatives (Bruvold, 1988; Devitt et al., 2004). Municipalities must first gain public acceptance before embarking on a water reuse program.

In a few communities, reuse water is used residentially [Environmental Protection Agency (EPA), 1992]. Active reuse programs are typically used to irrigate golf courses, 
parks, and roadway medians where public acceptance is highest and human contact is perceived to be low. However, as water shortages occur and the cost of municipal water rises, public acceptance has broadened to include its use at power plants, industrial plants and for fire protection, dust control, groundwater recharge, and the irrigation of nonedible crops (EPA, 1992). Golf course superintendents in the southwest reported little opposition to using reuse water for dust control or to irrigate golf courses, parks, home lawns, or crops (Devitt et al., 2004).

Although reuse water is a reliable source of water even during drought, users must be aware of the risks associated with using reuse water. These risks include possible human health-related problems, soil salinization and plant damage, leached nutrients as environmental contaminants, and the loss in aesthetic value of water features (ponds, streams, and fountains).

Quality of reuse water depends on the quality of the municipal water, the contaminant or pollutant contributions from the industrial sector, and the level of treatment imposed before discharge. Thus, quality of reuse water will vary according to the community. Although primary (removal of floating and settling solids) and secondary (removal of suspended solids) treated effluents have been used in many different settings, reuse water should receive tertiary (removal of pathogens) treatment if the general public will come in direct contact with the reuse water. Most epidemiological studies have shown little evidence of increased risk of infection or increased disease occurrence related to spray irrigation with wastewater. In the rare case in which illness was reported, it was associated with raw or primary treated effluent, not tertiary effluents (Camann et al., 1986; Camann and Moore, 1987; Fattal et al., 1987). Yanko (1992) reported no detectable viral hazard associated with California water reuse programs when reuse water was used to irrigate parks, urban landscapes, agricultural crops, or used for groundwater recharge. Furthermore, Tanaka et al. (1998) showed that annual infection risk associated with various uses of reclaimed water that met California reclamation criteria was one in 10,000 . This risk factor is less than potable water. The American Water Works Association (AWWA) concluded that recycled water that has been approved by regulatory agencies is safe and has urged the public to accept use of recycled water (AWWA, 1997). If tertiary treated water is used, health risks are generally small but should not be ignored. Users of reuse water should minimize contact time, especially aerosol inhalation, maintain proper hygiene by washing hands before eating, and wear rubber gloves to minimize contamination when coming in direct contact with this water.

Salinity. Because reuse water in a community typically contains twice the salt load of the municipal water, there is an enhanced potential for salinity problems if this water is used in the urban landscape. In the case of Las Vegas, NV, that means increasing the salinity from $0.95 \mathrm{dS} \cdot \mathrm{m}^{-1}$ to $\approx 2.0 \mathrm{dS} \cdot \mathrm{m}^{-1}$. Such reuse waters contain salt at 12,000 $\mathrm{kg} \cdot \mathrm{ha} \cdot \mathrm{m}^{-1}$ (1.6 tons of salt per acre-foot of water) and would have slight to moderate restrictions on its use (Ayers and Westcot, 1976). However, such classification assumes good irrigation management. To ensure good management when irrigating with reuse water, the leaching fraction and the uniformity of the irrigation system must be closely monitored and properly adjusted. The leaching fraction, also known as the leaching requirement, is the fraction of irrigation water that must deep percolate beyond the root zone to maintain a set EC in the plant's root zone. Deficit irrigating with water containing salt at $12,000 \mathrm{~kg} \cdot \mathrm{ha} \cdot \mathrm{m}^{-1}$ can be done for short periods, but lack of a long-term leaching program will lead to substantial salinization of the soil profile. Uniformity of applied irrigation dictates the distribution of salts and ultimately spatial salinization of surface soils and soil profiles. Although increasing the leaching fraction can somewhat compensate for poor uniformity, this leads to poorer irrigation efficiencies. As the price of water increases, the economic tradeoff between increased units of applied water versus improving irrigation efficiencies becomes clearer (Leskys et al., 1999).

Landscape irrigation management and plant salt injury. Only a small percentage of plant species planted in urban landscapes have been evaluated fully for salt tolerance (Costello et al., 2000). Several popular landscape trees and shrubs are very sensitive to soil salinity (Miyamoto et al., 2004). So, to maintain landscape quality after transitioning to reuse water, many existing landscape plants might have to be replaced with more salt-tolerant taxa. Furthermore, water quality can be modified and irrigation management practices can be changed. Irrigators must maintain soil salinity levels below threshold values (if known) by maintaining adequate leaching and by minimizing wide oscillations in soil water content between irrigation events. As soil water is depleted, it will drive greater oscillations in soil salinity. Soil salinity is difficult to quickly reverse; therefore, landscape managers, golf course superintendents, and park managers must evaluate soil salinity at least yearly if reuse water is used for irrigation.

Many ornamental landscape species are also sensitive to foliar application of reuse water (Miyamoto et al., 2004). If water can be directed to the base of the plant through drip irrigation or bubblers, some of this damage can be avoided. On mixed urban landscape areas, direct or indirect spray from turfgrass irrigations often splash on the foliage of sensitive landscape species. If these areas cannot be isolated from foliar spray, substituting new species that have greater tolerance to foliar application of salts or plant management strategies that minimize foliar contact with this water such as canopy pruning will be required. Postirrigation rinse can minimize the extent of foliar damage, but results are very species-specific. Also, certain salts are more damaging than others. For example, chloride salts are typically more damaging than sulfate salts, and sodium salts are more damaging than calcium salts. Magnesium chloride caused greater foliar damage to all tree species studied with mortality recorded in privets (Ligustrum japonicum Thunb.) (Devitt et al., 2005c). Knowledge of the ionic composition of the irrigation water is critical, and landscape managers should aim to minimize concentrations of sodium, magnesium, and chloride in reuse waters.

Lists ranking the visual damage of various species irrigated with reuse water have been published (Devitt et al., 2005b; Jordan et al., 2001; Miyamoto et al., 2004; Quist et al., 1999). Only seven of 19 tree species whose foliage intercepted reuse water from overhead irrigations had acceptable visual ratings (Jordan et al., 2001). However, shade increased flower production and improved visual appearance of landscape plants that were irrigated with reuse water (Devitt et al., 2005b). This suggests that multistory landscapes may be a good approach to minimizing visual damage to flowering plants. Therefore, to limit plant damage and salinity-related problems in the urban landscape, irrigation managers must use multiple approaches to manage reuse water in the urban landscape (Devitt et al., 2003).

Nitrogen management. One of the positive features of most reuse waters is the nitrogen content. Color ratings of turfgrass (Brown et al., 2004) and health of many landscape plants are closely linked to nitrogen application rates. Irrigation volume is directly related to nitrogen loading. Fortunately, the greatest volumes occur during summer months when plants are actively growing and taking up large amounts of nitrogen. To prevent nitrogen from becoming an environmental contaminant, landscape managers must reduce nitrogen applications based on the amount of free nitrogen in the reuse water.

Although nitrogen and other nutrients in reuse water benefit plant growth, they can contribute to algal growth in water features such as irrigation ponds, streams, and fountains. Turbidity is typical of ponds containing reuse water. Phosphate-P is usually the controlling factor; as concentrations exceed 0.50 $\mathrm{mg} \cdot \mathrm{L}^{-1}$, algal production increases. Devitt et al. (2005a) reported low phosphate-P concentrations in a reuse pond that had a well-established stand of aquatic vegetation. However, when the vegetation was removed, phosphate-P concentrations increased and clarity decreased. Spectral reflectances of ponds are highly correlated with $\mathrm{pH}$, clarity, and algal chlorophyll concentration. In one study, Devitt et al. (2005a) showed that spectral reflectance of ponds had either two peaks at $\approx 550 \mathrm{~nm}$ and $705 \mathrm{~nm}$ (high algal content) or only a single peak at $550 \mathrm{~nm}$ (low algal content). This suggests that landscape managers can possibly use reflectance values to determine when to initiate management 
decisions that will improve overall pond clarity.

Nursery runoff and constructed wetland effluent as sources of reuse water. Although efficient irrigation scheduling and lowvolume water application technology can reduce runoff, nurseries (Fare et al., 1992) and garden centers generate substantial volumes of nutrient-rich runoff associated with daily overhead sprinkler irrigation and frequent fertigation of containerized plants grown in porous growing substrates. Federal regulations generally require nurseries to retain all applied irrigation water on location and detain the first $1.27 \mathrm{~cm}(0.5 \mathrm{in})$ of each precipitation on-site (EPA, 1982). Therefore, nurseries could potentially become an important source of reuse water if plants that can thrive on water captured from the nursery are known or the nursery runoff water is treated to make it suitable for use in the urban landscape.

One practical way to render nursery runoff suitable for the urban landscape is to filter it through constructed wetlands built at the nursery site. Constructed wetlands can either be subsurface flow-constructed wetland, which consists of an aggregate filter such as gravel, in which water flows below the surface, or free surface flow-constructed wetland, which mimics natural bogs or wetlands with shallow open water over soil in which emergent or floating plants are placed.

Constructed wetlands can potentially remove nitrates (Hammer, 1989; Kadlec and Knight, 1996), a variety of organic compounds, nitrogen, and sometimes phosphorus compounds (Bilderback et al., 1993; Fernandez et al., 1999; Hammer, 1989; Holt et al., 1999; Kadlec and Knight, 1996) from nursery runoff water. Running nursery runoff through a constructed wetland might render it suitable for use in the urban landscape. For example, commercial quality sunflower blooms (Helianthus annuus L. 'Mammoth') were produced when plants were irrigated with direct runoff, recycled wetland effluent, or salt-injected water (Arnold et al., 2003). However, the number of inflorescences receiving the highest quality rating was less when plots were irrigated with direct runoff, recycled wetland effluent, or salt-injected water compared with municipal tap water (Table 2).

\section{Ordinances, Incentives, Policies, and Urban Landscape Water Conservation}

Landscape ordinances. Although most urban and suburban residents in the United States (even those in arid and semiarid regions), seldom experience water shortages at the tap (Kenney et al., 2004), declining water supplies, and the possibility of real water shortages are forcing municipalities to pass landscape ordinances that severely restrict outdoor watering. A landscape ordinance establishes that a community is committed to the long-term environmental care and improvement of the landscape (Abbey, 1998). Typically, communities enact one of

Table 2. Inflorescence quality and stand density of Helianthus annuus 'Mammoth' receiving direct nursery runoff (runoff), single-pass wetland treated nursery runoff (recycled), $3.0 \mathrm{dS} \cdot \mathrm{m}^{-1}$ sodium chloride spiked water (salt), or municipal water (tap).

\begin{tabular}{lcc}
\hline Irrigation treatment & $\begin{array}{c}\text { Inflorescences receiving a top rating of five } \\
\text { (no./plot/harvest date) }\end{array}$ & Stand density (plants/plot) \\
\hline Runoff & $1.3 \mathrm{~b}^{\mathrm{z}}$ & $53.3 \mathrm{a}$ \\
Recycled & $1.0 \mathrm{~b}$ & $37.3 \mathrm{ab}$ \\
Salt & $1.2 \mathrm{~b}$ & $29.3 \mathrm{~b}$ \\
Tap & $2.9 \mathrm{a}$ & $44.2 \mathrm{ab}$ \\
\hline
\end{tabular}

${ }^{z}$ Means within a column followed by the same letter are not significantly different at $P \leq 0.05$. Data from Arnold et al. (2003).

the following three types of landscape ordinances: 1) a Comprehensive Landscape Ordinance, which regulates landscaping as well as land alteration, tree protection and removal, storm water management, erosion control, groundwater recharge, and land clearing; 2) a Post Construction Landscape Ordinance, which requires planting after construction and usually integrates standards for irrigation and maintenance; and 3) or a Tree Ordinance, which is responsible for the regulation, care, and maintenance of street, park, and other public trees. In the United States, tree ordinances are the oldest type of landscape ordinance with the earliest recorded ordinance being the Pennsylvania Shade Tree Law of the 18th century (Abbey, 1998).

Although the modern U.S. landscape ordinance can trace its beginnings to the 1949 court decision in Ayres vs. City Council of Los Angeles, which upheld the city's decision to require a 10 -foot planting strip in the rear lot of a subdivision, since the 1990s, landscape ordinances have shifted toward water-efficient landscape design (Abbey, 1998). With increasing frequency, municipalities in the United States, particularly those in arid and semiarid regions, are adopting ordinances that specifically target water conservation in the urban landscape.

Some municipalities mandate the use of plants that are adapted to the local climate and need little or no additional water after plants are established. These ordinances restrict the use of turf, list plants that can be used in the outdoor landscape, or regulate the type of irrigation allowed. For that reason, many cities and municipalities are writing or updating their model water-efficient landscape ordinances. For example, CA Water Bill, AB 1881, mandates an update of the state's model water-efficient landscape ordinance, which local agencies will have to adopt in Jan. 2010 (Landscape Contractor, 2008). The purpose of California's bill is to mandate performance standards and labeling requirements for landscape irrigation equipment to reduce energy and water consumption (Landscape Contractor, 2008).

Landscape ordinances that are created after an urban residential area is built will potentially face resistance from the affected residents. One way to circumvent this potential problem is to develop a conservation division that mandates water conservation procedures while subdivisions are being planned. According to Arendt (1999), this could be the single most effective way for communities to conserve their natural resources such as water.

When landscape ordinances are adopted after a residential area is built, municipalities must be clear on how to respond to long-term and short-term efficient irrigation issues. Because conservation programs that include mandatory water restrictions are more effective than voluntary restrictions (Kenney et al., 2004), ordinances must feature mandatory water restrictions to cope with a drought crisis. Thus, effective ordinances should have the right balance between the long-term need for efficient water use in the urban landscape and the need to respond to drought crisis.

Implementing landscape ordinances. Increasingly, legislatures are proposing bills that promote the efficient use of water in the urban landscape. A systematic, fair, and proven approach must be used to get communities to support those ordinances. Based on the success in implementing municipal landscape ordinances (Cook, 2008), the following steps to develop a municipal landscape ordinance have been proposed: 1) generate community buy-in at the start of development of a landscape ordinance by meeting with all groups opposed to the ordinance first, not last; 2) educate the public about the benefits of efficient landscape techniques such as drip irrigation; 3) provide the public with specific examples of savings of efficient irrigation techniques; and 4) develop a flexible point system for compliance with the landscape ordinance. For example, five points might be awarded toward ordinance compliance if a rain sensor is included with the irrigation system. In contrast, five points might be deducted if an irrigation plan is not included with the building permit.

Incentives. Instead of mandating ordinances, water districts, municipalities, and states might offer incentives to promote more efficient water use in the urban environment. Economic incentives include changes to water rate schedules that increase costs with increasingly higher levels of water use and xeriscape ${ }^{\mathrm{TM}}$ incentive programs that, for example, offer cash payments to eliminate traditional turfgrass lawns. Noneconomic strategies include strategies that raise awareness, develop attitudes of responsibility toward water resources, enhance xeriscaping of community and public landscapes, and increase access to information and guidance on landscape conversions. 
One economic incentive program, often called "Cash for Grass," offers rebates for conversion of turf to xeriscapes. The cost of the rebates for each square meter of turf converted to a water-conserving landscape have ranged from $\$ 5.92$ (Albuquerque, NM) to $\$ 14.32$ (El Paso, TX) (Addink, 2008). The annual calculated water savings ranged from 733 to $2,526 \mathrm{~L}$ per square meter of turf removed. Based on the costs incurred during the first year of conversion, the cost per $1,233,532 \mathrm{~L}$ (1 acre-foot) of water saved was $\$ 6,714$ and $\$ 6,990$ in the North Marin Water District, CA, and Southern Nevada programs, respectively, and $\$ 9,433$ and $\$ 24,077$ in the Albuquerque, NM, and El Paso, TX, programs, respectively. This led Addink (2008) to conclude that "Cash for Grass" programs are an expensive way to save water.

Water districts and municipalities in several states also offer rebates to clients who purchase irrigation controllers that adjust watering schedules based on weather conditions (ET controllers). For example, the Southern Nevada Water Authority (2008) and San Diego County Water Authority (2008) offer up to $\$ 200$ and $\$ 350$ rebates on the purchase of ET controllers, respectively. Because ET controllers offer a new way to efficiently irrigate the landscape, providing consumers incentives to use those ET controllers could be one way to promote irrigation efficiency.

Federal and state policies. Federal and state policies shape how local governments balance water demand with growth by their investment in water infrastructure and their authority over local planning and municipal finance (EPA, 2006). Federal funding to states contribute to their Safe Drinking Water and Clean Water State Revolving Funds. Although this funding is primarily for safe drinking water, states can distinguish among projects that rank equally on the three main federal priorities and select projects that meet other community needs such as smart growth and water conservation (EPA, 2006). On the other hand, state policies might not be specific enough for local communities to match their water needs with the available water supply. Therefore, communities might have to plan their water budget because the local community has a better understanding of locally available water resources (EPA, 2006).

Even if local municipalities have a good understanding of their local water supplies, in some regions, water law dictates that beneficial use shall be the measure and limit of the water right. In this case, adjudication of water rights might impact how water is allocated to the urban landscape. For example, in New Mexico, agricultural irrigation accounts for greater than $80 \%$ of diversions of water. Furthermore, with water law precedence being first in time, first in right, water designated for agricultural use has very early priority dates. This means that transfer of water from agricultural use to municipal use and subsequently to landscape use might not always be easy. When water transfers are possible, only the amount of water that will be lost to crop evapotranspiration or incorporated into the crop (crop consumptive use) is often permitted. Therefore, detailed landscape water budgets are needed to ensure that the right amount of water is transferred. In most states, the transfer of water rights will involve the Office of the State Engineer (OSE).

There are two basic reasons that alignment of water conservation plans with those of the OSE will benefit municipalities. First, the OSE can help form entities that own or lease water rights and this can be done to benefit the urban landscape. Second, the OSE may reject a municipality's water conservation plan if it contradicts the state's water conservation plan. As an example, New Mexico law [New Mexico Subdivision Act (NMAC 47.6.11)] requires counties to include water conservation plans before they can build new subdivisions. The effect of this law is that each county has a fixed water allotment per parcel for the proposed new subdivision (New Mexico OSE, 2008). This promotes efficient use of water in the urban landscape. Previously, the state allowed communities to build first and secure water rights later, which did not lead to water conservation.

Water pricing. In this review, we do not discuss the merits of the different water pricing models. However, in the western United States, it is speculated that the low cost (average of $\$ 0.00058$ per gallon) of potable water is contributing to its premature depletion (Brookshire et al., 2002). Increasing awareness of water scarcity concerns should enable water purveyors to command higher prices for water (Johnson et al., 2001). However, this is not happening for water because there is no significant evidence that elasticity values will change over time (Dalhuisen et al., 2003). To engender more appropriate pricing levels for water, current pricing models might need to be re-examined to provide stronger incentives for water conservation. For example, the block rate pricing model that is used in many municipalities conflicts with standard economic assumptions that price setting is quantityindependent (Dalhuisen et al., 2003). Newer water pricing models such as the Irvine Ranch Water District's (IRWD) tiered-rate structure that is based on a water budget should be used to promote the efficient use of water in the urban landscape. The IRWD water pricing model provides customers with economic signals as their water use increases and this has created a decrease in water consumption while creating an increase in urban landscape health (Irvine Ranch Water District, 2008b).

\section{Summary and Recommendations}

Because water resources are becoming scarce, there is increasing demand to improve efficiency of water use in the urban landscape, which uses most of the residential water supply. Furthermore, many communities are mandating better use of water used for outdoor landscapes, which makes implementation of those water-efficient landscapes inevitable. Improving landscape irrigation uniformity enhances efficiency of water use in the urban environment. However, irrigation uniformity is driven by performance of the components of the irrigation system and management decisions. To secure the most efficient use of water in urban landscapes, we recommend that communities specify the level of uniformity and management needed for their irrigation systems.

Water application technologies such as controllers that schedule irrigation based on environmental conditions and soil moisture sensors that interrupt irrigation based on soil moisture can improve water management decisions. Municipalities must seriously consider adopting those technologies as part of their long-term landscape irrigation plans.

Besides identifying the level of uniformity and using water application technologies, urban water managers must determine accurately water budgets and appropriately schedule irrigations. An urban landscape water budget, also known as its maximum applied water allowance, can be calculated to provide a quantitative estimate of an urban landscape's water budget. Current research, although somewhat limited, shows that some landscapes can maintain acceptable aesthetic appearance with less water than is indicated from a calculated water budget. Furthermore, water budgets can be used to craft a tier rate water pricing structure as has been done successfully at the Irvine Ranch Water District. Because the tier rate water pricing structure that is based on a water budget decreases water consumption without compromising the quality of the landscape, municipalities that are committed to efficient water use in the urban landscape might want to consider a similar water pricing structure.

Aesthetically pleasing landscapes and water-efficient landscapes are not mutually exclusive concepts. One way to engender a water-efficient landscape is to use a xeriscape $^{T M}$. A xeriscape ${ }^{T M}$ is based on seven principles and is designed to conserve water (Smith and St. Hilaire, 1999). However, homeowners consistently show a preference for traditional, nonwater-conserving landscapes. To enhance consumer acceptance of water-efficient landscapes, results from studies on responses to and preferences for landscapes can be applied to the design of water-efficient landscapes. People are more likely to accept water-efficient landscapes if they are orderly, contain green-foliaged trees with spreading canopies, and incorporate a sense of mystery.

Regardless of landscape type, the use of reuse water in the urban landscape is a strategy that communities can use to offset water supply shortages. However, when irrigating the urban landscape with reuse water, greater management skills are required to minimize soil salinization, plant damage, health-related problems, and loss in aesthetic 
appearance of water features. Nitrogen and other nutrients in reuse water can benefit landscape plants. However, reliance on reuse water as nutrient source must be balanced with the potential for reuse water to deteriorate the functionality of water features such as irrigation ponds, streams, and fountains.

Neglected sources of water such as nursery runoff can be filtered through constructed wetlands and used to irrigate the urban landscape. This could improve the usefulness of this water. Current regulations require nursery and garden centers to retain irrigation runoff on-site. Therefore, water purveyors should be vigilant for regulations that provide opportunities for new sources of water to be used in the urban landscape.

In addition to nursery and garden center runoff regulations, ordinances that seek to regulate water use in the urban landscape abound. Although landscape ordinances started 50 years ago, the modern landscape ordinance is becoming focused on water conservation in the urban landscape. To be effective, landscape ordinances must have elements to manage both their short- and long-term efficient irrigation needs.

Landscape ordinances that target water conservation might be more effective if they are aligned with the water conservation plans of state and federal agencies. Implementing a landscape ordinance that promotes efficient water use in the urban environment might create discord in a community. Therefore, legislators must follow a process that creates an ordinance that is suitable to all stakeholders. This process should include meeting with all parties opposed to the ordinance first, not last.

\section{Literature Cited}

Abbey, D.G. 1998. U.S. landscape ordinances: An annotated reference handbook. John Wiley and Sons, New York, NY.

Addink, S. 2008. 'Cash for grass'-A cost effective method to conserve landscape water? $11 \mathrm{Feb}$. 2008. <http://ucrturf.ucr.edu/topics/Cash-forGrass.pdf>.

Allen, R.G., L.S. Pereira, D. Raes, and M. Smith. 1998. Crop evapotranspiration: Guidelines for computing crop water requirements. Irrigation and Drainage Paper No. 56. FAO, Rome, Italy.

American Society of Agricultural and Biological Engineers (ASAE). 1985. ASAE S398. 1. Procedure for sprinkler testing and performance reporting. ASAE, St. Joseph, MI.

American Water Works Association Research Foundation. 1997. Guidelines for the on-site retrofit of facilities using disinfected tertiary recycled water. Residential end uses of water. American Water Works Association, Denver, CO. 21 Jan. 2006. <http://www.awwarf.org/ research/topicsandprojects/execSum/241.aspx>.

Arendt, R. 1999. Growing greener: Putting conservation into local plans and ordinances. Island Press, Washington, DC.

Arnold, M.A., B.J. Lesikar, G.V. McDonald, D.L. Bryan, and A. Gross. 2003. Irrigating landscape bedding plants and cut flowers with recycled nursery runoff and constructed wetland treated water. J. Environ. Hort. 21:89-98.

Ayers, R.S. and D.W. Westcot. 1976. Water quality for agriculture. FAO, Rome, Italy.
Balok, C.A. and R. St. Hilaire. 2002. Drought responses among seven southwestern landscape tree taxa. J. Amer. Soc. Hort. Sci. 127:211-218.

Beeson, R.C., Jr. 2005. Modeling irrigation requirements for landscape ornamentals. HortTechnology 15:18-22.

Bilderback, T.E., M.A. Powell, T.M. Losordo, S.W. Broome, and S.H. Kay. 1993. An aquatic plant production and nutrient mitigation system. Southern Nurseryman Assoc. Res. Conf. Proc. 38:422-426.

Brookshire, D.S., H.S. Burness, J.M. Chermak, and K. Krause. 2002. Western urban water demand. Nat. Resour. J. 42:873-893.

Brown, C.A., D.A. Devitt, and R.L. Morris. 2004 Water use and physiological response of tall fescue turf to water deficit irrigation in an arid environment. HortScience 39:388-393.

Brown, L.T. and K.R. Pharr. 2007. Forum: University actively looking for additional ways to conserve water. Athens Banner-Herald, 25 Oct. 2007. 10 Nov. 2007. <http://www.onlineathens.com/ stories/102507/opinion_20071025037.shtml>.

Bruvold, W.H. 1988. Public opinion on water reuse options. J. Water Pollut. Control Fed. 60:45-49.

Burt, C.M., A.J. Clemmens, T.S. Strelkoff, K.H Solomon, R.D. Bliesner, L.A. Hardy, T.A. Howell, and D.E. Eisenhauer. 1997. Irrigation performance measure: Efficiency and uniformity. J. Irrig. Drain. Eng. 123:423-442.

California Department of Water Resources. 2005. California water plan update 2005. California Department of Water Resources Bulletin 16005. 15 Mar. 2006. <http://www.waterplan.water. ca.gov/cwpu2005/index.cfm\#highlights>.

California Office of Water Use Efficiency. 2006. Landscape water use program. California Department of Water Resources, Sacramento, CA. 15 Apr. 2006. <http://www.owue.water. ca.gov/landscape/index.cfm>.

California Urban Water Conservation Council. 1991. revised 2005). Memorandum of understanding. 15 Apr. 2006. <http://www.cuwcc. org/memorandum.lasso $>$.

Camann D.E., P.J. Graham, M.N. Guentzel, H.J. Harding, K.T. Kimball, B.E. Moore, R.L. Northop, N.L. Altman, R.B. Harrist, A.H. Holguin, R.L. Mason, C.Becker Popescu, and C.A. Sorber. 1986. The Lubbock land treatment system research and demonstration project: Volume 4 Lubbock infection surveillance study (LISS). EPA/600/S2-86/027d.

Camann, D.E. and B.E. Moore. 1987. Viral infections based on clinical sampling at a spray irrigation site. Water reuse symposium: Proc. of water reuse symposium 4. Denver, CO.

Chaves, M.M., J.P. Maroco, and J.S. Pereira. 2003. Understanding plant responses to droughtFrom genes to the whole plant. Funct. Plant Biol. 30:239-264

City of El Paso. 1991. Car wash ordinance No. 15106. 10 Nov. 2007. <http://www.elpasotexas. gov/muni_clerk/ordinances.asp>.

Colorado Department of Local Affairs. 2004 Model water-efficient landscape design ordinance. 15 Nov. 2006. <http://www.dola.state.co.us/ smartgrowth/documents/Water\%20Efficient $\%$ 20Landscaping\%20Design.pdf $>$.

Conservation Current. 2008. AWWA 2008 Sustainable Water Sources Conference highlights. 21 May 2008. <http://www.conservationcurrent. org/\#riverx>.

Cook, K. 2008. Water conservation and the municipal landscape ordinance: Implementing a successful relationship in the 21 st century. $22 \mathrm{Feb}$. 2008. <http://cahe.nmsu.edu/academics/land scape/documents/kcook.pdf>.
Costello, L.R. and K.S. Jones. 2000. Water use classification of landscape plants (WUCOLS III). 4 Jan. 2006. <http://www.owue.water.ca. gov/docs/wucols00.pdf>.

Costello, L.R., K.S. Jones, and D.D. McCreary. 2005. Irrigation effects on the growth of newly planted oaks (Quercus spp.). J. Arboricult. 31:83-88.

Costello, L.R., N.P. Matheny, and J.R. Clark. 2000. A guide to estimating irrigation water needs of landscape planting in California. Univ. Calif. Coop. Ext.

Cotter, D.J. and D.B. Croft. 1974. Water application practices and landscape attributes associated with residential water consumption. New Mexico Water Resources Res. Institute Report C-049, New Mexico State Univ., Las Cruces, NM.

Council of Tree and Landscape Appraisers. 2003. Guide for plant appraisal. 9th Ed. Intl. Soc. Arboricult., Champaign, IL.

Dalhuisen, J.M., R.J.G.M. Florax, H.L.F. de Groot, and P. Nijkamp. 2003. Price and income elasticities of residential water demand: A meta-analysis. Land Econ. 79:292-308.

Davis, S., M.D. Dukes, S. Vyapari, and G.L. Miller. 2007. Evaluation and demonstration of evaporation-based irrigation controllers. Proc. ASCE EWRI World Environmental and Water Resources Congress, 15-19 May 2007, Tampa, FL.

Denver Water Department. 1982. Water conservation through creative landscaping: Xeriscape garden. Office of Water Conservation, Denver Water Dept., Denver, CO.

Devitt, D.A., R.A. Morris, and D.S. Bowman. 1994. Evapotranspiration and growth response of three woody ornamental species placed under varying irrigation regimes. J. Amer. Soc. Hort. Sci. 119:452-457.

Devitt, D.A., R.A. Morris, and D.S. Neuman. 2003. Impact of water treatment on foliar damage of landscape trees sprinkle irrigated with reuse water. J.Environ. Hort. 21:82-88.

Devitt, D.A., R.L. Morris, and D.C. Bowman. 1992. Evapotranspiration, crop coefficients, and leaching fractions of irrigated desert turfgrass systems. Agron. J. 84:717-723.

Devitt, D.A., R.L. Morris, D. Kopec, and M. Henry. 2004. Golf course superintendents attitudes and perceptions toward using reuse water for irrigation in the southwestern United States. HortTechnology 14:1-7.

Devitt, D.A., D.S. Neumn, D.C. Bowman, and R.L Morris. 1995. Water use of landscape plants in an arid environment. J. Arboricult. 21:239245.

Devitt, D.A., R.L. Morris, M. Baghzouz, M. Lockett, and L.K. Fenstermaker. 2005a. Water quality changes in golf course irrigation ponds transitioning to reuse water. HortScience 40:21512156.

Devitt, D.A., R.L. Morris, L.K. Fenstermaker, M. Baghzouz, and D.S. Neuman. 2005b. Foliar damage and flower production of landscape plants sprinkle irrigated with reuse water. HortScience 40:1871-1878.

Devitt, D.A., R.L. Morris, and L.K. Fenstermaker. $2005 \mathrm{c}$. Foliar damage, spectral reflectance, and tissue ion concentrations of trees sprinkle irrigated with waters of similar salinity but different chemical composition. HortScience 40:819-826.

Dickinson, M. 2008. Water conservation in the United States: A decade of progress. 10 Jan. 2008. <http://wwa.colorado.edu/resources/ water_demand_and_conservation/US_Water ConservationProgress_Dickinson.pdf $>$. 
Dwyer, J.F., H.W. Schroeder, and P.H. Gobster. 1991. Central hardwood forest resources: A social science perspective. General technical report NE 148-USDA Forest Service, Northeastern Forest Expt. Sta.

Emrath, P. 2000. Residential water use. Housing Economics 48:6-10.

Environmental Protection Agency. 1982. Manual of individual water systems, EPA-570/9-82004. Environmental Protection Agency, Office of Drinking Water, Washington, DC.

Environmental Protection Agency. 1992. Guidelines for water reuse. EPA/625/R-92/004247.

Environmental Protection Agency. 2006. Growing toward more efficient water use. Linking development, infrastructure, and drinking water policies, EPA 230-R-06-001. January .

Fare, D.C., C.H. Gilliam, and G.J. Keever. 1992. Monitoring irrigation at container nurseries. HortTechnology 2:75-78.

Fattal, B., M. Margalith, H.I., Y. Shuaval, Y. Wax, and A. Morag. 1987. Viral antibodies in agricultural populations exposed to aerosols from wastewater irrigation during a viral disease outbreak. Am. J. Epidemiol. 125:899-906.

Ferguson, B.K. 1987. Water conservation methods in urban landscape irrigation: An exploratory overview. Water Resour. Bull. 23:147-152.

Fernandez, R.T., T. Whitwell, M.B. Riley, and C.R. Bernard. 1999. Evaluating semiaquatic herbaceous perennials for use in herbicide phytoremediation. J. Amer. Soc. Hort. Sci. 124:539-544.

Gibeault, V.A., S.T. Cockerham, J.M. Henry, and J. Meyer. 1990. California turfgrass: It's use, water requirement and irrigation. Calif. Turfgrass Cult. 39:1-9.

Gimblett, H.R., R.M. Itami, and J.E. Fitzgibbon. 1985. Mystery in an information processing model of landscape preference. Landscape J. 4:87-95.

Graves, W.R. 1996. Drought resistance in trees: An overview of mechanisms and new research with Iowa's black maples. Proc. of the 9th Metropolitan Tree Improvement Alliance (METRIA) conference, Columbus, OH, 8-10 Aug. 1996. 12 May 2008. <htt://www.ces.ncsu. edu/fletcher/programs/nursery/metria/metria09/ graves.html>.

Hagan, P. 1988. Gardening: X-rated drought relief. The Wall Street Jour., Leisure and Arts Section, p. 1.16 Aug.

Hammer, D.A. 1989. Constructed wetlands for wastewater treatment: Municipal, industrial and agricultural. Lewis Publ., Boca Raton, FL. p. 831.

Herzog, T.R. 1987. A cognitive analysis of preference for natural environments: Mountains, canyons, and deserts. Landscape J. 6:140-152.

Herzog, T.R. and O.L. Leverich. 2003. Searching for legibility. Environ. Behav. 35:459-477.

Holt, T.C., B.K. Maynard, and W.A. Johnson. 1999. Nutrient removal by five ornamental wetland plant species grown in treatment-production wetland biofilters. HortScience 34:521. (abstr.).

Hurd, B., R. St. Hilaire, and J. White. 2006. Residential landscapes, homeowner attitudes and water-wise choices in New Mexico. HortTechnology 16:241-246.

Irrigation Association. 2008. Smart controller efficiency testing. 21 Feb. 2008. <http://www. irrigation.org/SWAT/Industry/ia-tested.asp>.

Irvine Ranch Water District. 2008a. The residential runoff reduction study. 21 May 2008. <http:// www.irwd.com/Conservation/R3-Study-Revised115-04.pdf $>$.

Irvine Ranch Water District. 2008b. Water conservation and efficiency program. 15 Aug. 2008.
$<$ http://www.irwd.com/Conservation/Water Allocation.pdf>.

Johnson, N., C. Revenga, and J. Echeverria. 2001. Managing water for people and nature. Science 292:1071-1072.

Jordan, L.A., D.A. Devitt, R.L. Morris, and D.S. Neuman. 2001. Foliar damage to ornamental trees sprinkler irrigated with reuse water. Irrig. Sci. 21:17-25

Kadlec, R.H. and R.L. Knight. 1996. Treatment wetlands. Lewis Publ., Boca Raton, FL. p. 893.

Kaplan, R. 1985. Nature at the doorstep: Residential satisfaction and the nearby environment. J. Archit. Plann. Res. 2:115-127.

Kaplan, R. and S. Kaplan. 1989. The experience of nature: A psychological perspective. Cambridge Univ. Press, New York, NY.

Kaplan, R., S. Kaplan, and R.L. Ryan. 1998. With people in mind: Design and management of everyday nature. Island Press, Washington, DC

Kaufman, A.K. and V.I. Lohr. In press. Does it matter what color tree you plant? Eighth International People-Plant Symposium, Hyogo, Japan.

Kenney, D.S., R.A. Klein, and M.P. Clark. 2004. Use and effectiveness on municipal water restrictions during drought in Colorado. J. Amer. Water Resour. Assoc. 40:77-87.

King County Department of Development and Environmental Services. 2003. Zoning code-Irrigation system requirements. Bul. 19A. Renton, WA. 20 Apr. 2006. <http:// metrokc.gov/DDES/acrobat/cib/19a.pdf>.

Kirsch, T., F. Kaffarnik, M. Riederer, and L. Schreiber. 1997. Cuticular permeability of the three tree species Prunus laurocerasus L., Ginkgo biloba L. and Juglans regia L.: Comparative investigation of the transport properties of intact leaves, isolated cuticles and reconstituted cuticular waxes. J. Expt. Bot. 48:1035-1045.

Kjelgren, R., L. Rupp, and D. Kilgren. 2000. Water conservation in urban landscapes. HortScience 35:1037-1040.

Landscape Contractor. 2008. California water ordinance update, p. 55, Jan. 2008.

Leskys, A., D.A. Devitt, R.L. Morris, and L.S Verchick. 1999. Response of tall fescue to saline water as influenced by leaching fractions and irrigation uniformity distributions. Agron. J. 91:409-416.

Lewis, C.A. 1996. Green nature/Human nature: The meaning of plants in our lives. Univ. Illinois Press, Chicago, IL.

Lockett, L., T. Montague, C. McKenney, and D. Auld. 2002. Assessing public opinion on water conservation and water conserving landscapes in the semiarid southwestern United States. HortTechnology 12:392-396.

Lohr, V.I. 1991. Image boosters: Water-conserving landscapes. Amer. Nurse 173:86-90.

Lohr, V.I. and L.H. Bummer. 1992. Assessing and influencing attitudes toward water-conserving landscapes. HortTechnology 2:253-256.

Lohr, V.I., C.H. Pearson-Mims, J. Tarnai, and D.A. Dillman. 2004. How urban residents rate and rank the benefits and problems associated with trees in cities. J. Arboriculture 30:28-35.

Martin, C.A., K.A. Peterson, and L.B. Stabler. 2003. Residential landscaping in Phoenix, Arizona: Practices and preferences relative to covenants, codes and restrictions (CC\&Rs). J. Arboriculture 29:9-17.

Martin, C.A. and L.B. Stabler. 2004. Urban horticultural ecology: Interactions between plants, people and the physical environment. Acta Hort. 639:97-101.
Meyer, J.L., V.A. Gibeault, and V.B. Youngner. 1985. Irrigation of turfgrass below replacement of evapotranspiration as a means of conservation: Determining crop coefficients of turfgrass, p. 357-364. In: Lemaire, F. (ed.). Proc. of the 5th International Turfgrass Research Conference, Avignon, France, July 1985. INRA Publications, Versailles, France.

Miyamoto, S., I. Martinez, M. Padilla, A. Portillo, and D. Ornelas. 2004. Landscape plant lists for salt tolerance assessment. Texas A\&M Univ. Agri. Research Center at El Paso and El Paso Water Utilities. Apr. 2004.

Montague, T., R. Kjelgren, R. Allen, and D. Webster. 2004. Water loss estimates for five recently transplanted tree species in a semi-arid climate. J. Environ. Hort. 22:189-196.

Moore, N.Y., E.M. Pint, and L.M. Dixon. 1993. Assessment of the economic impact of drought on California's urban areas: A research agenda. RAND, Santa Monica, CA.

Muñoz-Carpena, R. 2004. Field devices for monitoring soil water content. Fla. Coop. Ext. Serv. Bul. 343 .

Natural Defense Resource Council. 2008. The consequences of global warming. 9 May 2008. <http://www.nrdc.org/globalWarming/ fcons.asp>.

New Mexico Office of the State Engineer. 2008. 21 Jan. 2008. <http://www.ose.state.nm.us/ index.html $>$.

Oliphant, J.C. 1989. Modeling sprinkler coverage with the SPACE program. Center for Irrigation Technology May Irrigation Notes CATI Publication No. 890802.

Pittenger, D.R., D.A. Shaw, D.R. Hodel, and D.B. Holt. 2001. Responses of landscape groundcovers to minimum irrigation. J. Environ. Hort. 19:78-84.

Pittenger, D.R., D.A. Shaw, and W.E. Richie. 2004. Evaluation of weather-sensing landscape irrigation controllers. 10 May 2008. <http:// ucce.ucdavis.edu/files/filelibrary/5764/21863. $\mathrm{pdf}>$.

Quist, T.M., C.F. Williams, and M.L. Robinson. 1999. Effects of varying water quality on growth and appearance of landscape plants. J. Environ. Hort. 17:88-91.

Redman, C. 1999. Human impact on ancient environments. Univ. Arizona Press, Tucson, AZ.

Relf, P.D. and V.I. Lohr. 2003. Human issues in horticulture. HortScience 38:984-993.

Richards, R.A., H.M. Rawson, and D.A. Johnson. 1986. Glaucousness in wheat: Its development and effect on water-use efficiency, gas exchange and photosynthetic tissue temperatures. Aust. J. Plant Physiol. 13:465-473.

Rooke, L. 1974. Water conserving landscapes for the arid west. Amer. Hort. Mag. 53:2022.

San Diego County Water Authority. 2008. Smart controller rebate for single-family homeowners (pilot program). 6 Mar. 2008. <http://www. sdcwa.org/manage/conservation-smartcontrollers_ single.phtml $>$.

Schroeder, H.W. and W.N. Cannon, Jr. 1987. Visual quality of residential streets: Both street and yard trees make a difference. J. Arboriculture 13:236-239.

Schuch, U.K. and D.W. Burger. 1997. Water use and crop coefficients of woody ornamentals in containers. J. Amer. Soc. Hort. Sci. 122:727734.

Shaw, D.A. and D.R. Pittenger. 2004. Performance of landscape ornamentals given irrigation treatments based on reference evapotranspiration. Acta Hort. 664:607-613. 
Shedd, M., M.D. Dukes, and G.L. Miller. 2007. Evaluation of evapotranspiration and soil moisture-based irrigation control on turfgrass. In: Kabbes, K.C. (ed.). Proc. ASCE EWRI World Environmental \& Water Resources Congress, 15-19 May 2007, Tampa, FL.

Smardon, R.C. 1987. Perception and aesthetics of the urban environment: Review of the role of vegetation. Landscape Urban Plan. 15:85-106.

Smith, C.S. and R. St. Hilaire. 1999. Xeriscaping in the urban environment, p. 241-250. In: Herrera, E.H. and J.G. Mexal (eds.). Ensuring sustainable development of arid lands. New Mexico J. Sci. Vol. 38. New Mexico Acad. Sci., Albuquerque, NM.

Snyder, R.L. and S. Eching. 2006. Urban landscape evapotranspiration. Vol. 4: Reference guide. In: California water plan update 2005, California Department of Water Resources Bul. 160-05. Sacramento, CA. 15 Mar. 2006. <http://www. waterplan.water.ca.gov/cwpu2005/index.cfm\# highlights $>$.

Solomon, K.H. 1989. A new way to view sprinkler patterns. Center for Irrigation Technology, August Irrigation Notes, CATI Publication No. 880802 .

Sommer, R. 1997. Further cross-national studies of tree form preference. Ecol. Psychol. 9:153160.

Southern Nevada Water Authority. 2008. Smart irrigation controller coupon. 6 Mar. 2008. $<$ http://www.snwa.com/html/cons_coupons_ smartclock.html>.
Sovocool, K.A., M. Morgan, and D. Bennet. 2006. An in-depth investigation of xeriscape as a water conservation measure. J. Amer. Water Works Assoc. 98:82-93.

Spinti, J.E., R. St. Hilaire, and D. VanLeeuwen. 2004. Balancing landscape preferences and water conservation in a desert environment. HortTechnology 14:72-77.

Staats, D. and J.E. Klett. 1995. Water conservation potential and quality of non-turf groundcovers versus kentucky bluegrass under increasing levels of drought stress. J. Environ. Hort. 13: 181-185.

Stabler, L.B. and C.A. Martin. 2004. Irrigation and pruning affect growth and water use efficiency of two desert-adapted shrubs. Acta Hort. 638:255-258.

State of California. 1993. Model water efficient landscape ordinance. 1 Apr. 2005. <http:// www.owue.water.ca.gov/docs/WaterOrdIndex. $\mathrm{cfm}>$.

Summit, J. and R. Sommer. 1999. Further studies of preferred tree shapes. Environ. Behav. 31:550-576.

Tanaka, H., T. Asano, E.D. Schroeder, and G. Tchobangglous. 1998. Estimating the safety of wastewater reclamation and reuse using enteric virus monitoring data. Water Environ. Res. 70:39-51.

Thayer, R.L., Jr. 1982. Public response to waterconserving landscapes. HortScience 17:562565 .
Tipton, J.L. 1994. Relative drought resistance among selected southwestern landscape plants. J. Arboriculture 20:150-155.

Unruh and Liverman. 2008. Changing water use and demand in the Southwest. 11 Aug. 2008. <http:// geochange.er.usgs.gov/sw/impacts/society/water_ demand $/>$.

U.S. Bureau of Reclamation. 2007. Weather and soil moisture based landscape scheduling devices, Technical Review Report. 2nd Ed. 21 Nov. 2007. <http://www.usbr.gov/lc/region/g4000/ conservation/docs/SmartController.pdf $>$.

Vrecenak, A.J. and L.P. Herrington. 1984. Estimation of water use of landscape trees. J. Arboriculture 10:313-319.

Wolfe, D.W., L. Ziska, C. Petzoldt, A. Seaman, L. Chase, and K. Hayhoe. 2008. Projected change in climate thresholds in the northeastern U.S.: implications for crops, pests, livestock, and farmers. Mitig. Adapt. Strategies Glob. Change 13:555-575.

Yanko, W. 1992. Analysis of 10 years of virus monitoring data from Los Angeles County treatment plants meeting California wastewater reclamation criteria. Water Environ. Res. 65:221-226.

Zoldoske, D.F., K.H. Solomon, and E.M. Norum. 1994. Uniformity measurements for turfgrass: What's best. Center for Irrigation Technology November Irrigation Notes.

Zube, E.H., J.L. Sell, and J.G. Taylor. 1982. Landscape perception: Research, application and theory. Landscape Planning 9:1-32. 